\title{
Cephalopod fauna of South Pacific waters: new information from breeding New Zealand wandering albatrosses
}

\author{
José C. Xavier ${ }^{1,2, *}$, Kath Walker ${ }^{3}$, Graeme Elliott ${ }^{3}$, Yves Cherel $^{4}$, David Thompson ${ }^{5}$ \\ ${ }^{1}$ Institute of Marine Research, Department of Life Sciences, University of Coimbra, 3001-401 Coimbra, Portugal \\ ${ }^{2}$ British Antarctic Survey, Natural Environment Research Council, High Cross, Madingley Road, CB3 0ET Cambridge, UK \\ ${ }^{3}$ Albatross Research, 594 Rocks Road, Nelson 7011, New Zealand \\ ${ }^{4}$ Centre d'Etudes Biologiques de Chizé, UMR 7372 du CNRS-Université de La Rochelle, BP 14, 79360 Villiers-en-Bois, France \\ ${ }^{5}$ National Institute of Water and Atmospheric Research Ltd., 301 Evans Bay Parade, Hataitai, Wellington 6021, New Zealand
}

\begin{abstract}
Cephalopods play an important ecological role in the Southern Ocean, being the main prey group of numerous top predators. However, their basic ecology and biogeography is still poorly known, particularly in the lightly sampled Pacific sector of the Southern Ocean. We collected and analysed information on cephalopods in that area, using Antipodean and Gibson's wandering albatrosses (Diomedea antipodensis antipodensis and D. antipodensis gibsoni, respectively) breeding at Antipodes Islands and Auckland Islands, respectively, in the New Zealand subantarctic islands as samplers, as they are known from tracking studies to cover huge areas of the Pacific sector of the Southern Ocean (Antipodean wandering albatrosses mostly forage east of New Zealand, whereas Gibson's wandering albatrosses forage west of New Zealand). A total of 9111 cephalopod beaks, from 41 cephalopod taxa, were identified from boluses (voluntarily regurgitated items by chicks). The families Histioteuthidae (e.g. Histioteuthis atlantica) and Onychoteuthidae (e.g. Moroteuthis robsoni) were the most important cephalopods numerically and by reconstructed mass, respectively, in both wandering albatross species. Combining this information with previously gathered data on cephalopods in the Atlantic and Indian sectors of the Southern Ocean, we provide evidence from predators of the circumpolar distribution of numerous key cephalopod species in the Southern Ocean, and provide new information on poorly known cephalopods (i.e. relevance in the diet of wandering albatrosses, sizes consumed, biodiversity in the South Pacific, assemblages according to predator breeding sites) in one of the most remote ocean areas in the planet.
\end{abstract}

KEY WORDS: Squid $\cdot$ Histioteuthidae $\cdot$ Onychoteuthidae $\cdot$ Distribution $\cdot$ Biodiversity $\cdot$ Predatory sampling $\cdot$ Diomedea antipodensis $\cdot$ Seabird $\cdot$ Southern Ocean

\section{INTRODUCTION}

There remains much to be learnt about cephalopod systematics and biogeography, and our knowledge of this group is relatively poor compared to that of other marine taxa (Roeleveld 1998). Cephalopods are widely distributed throughout all oceans, inhabit diverse ecosystems, including coastal shelves, open oceans and the deep sea, and support important fisheries worldwide (Hunsicker et al. 2010). Approximately 800 species of cephalopods have been described, including demersal species (e.g. octopods) and pelagic cephalopods, primarily squids (Boyle \& Rodhouse 2005). 
In the Southern Ocean (defined here as south of the subtropical front), the cephalopod fauna is particularly poorly known, despite growing evidence that cephalopods play an important role in Antarctic marine ecosystems (Collins \& Rodhouse 2006, Murphy et al. 2007, Xavier \& Cherel 2009, Rodhouse et al. 2014). Cephalopods exhibit a 'live fast and die young' life cycle (i.e. fast growth rate with semelparity as a reproductive strategy), which can result in either positive or negative effects in response to environmental change: due to having a fast life cycle, with numerous species living 1-2 yr only (Boyle \& Rodhouse 2005), cephalopods can be both sensitive (in terms of rapid response; e.g. if environmental conditions are unfavourable, cephalopod populations could be highly affected) and resilient (in terms of recovery; e.g. if environmental conditions promote habitat expansion, cephalopod populations may be able to recover quickly) to phenomena such as overfishing, and climate variability and change (Pecl \& Jackson 2008, André et al. 2010, Rodhouse 2013, Constable et al. 2014). One of the main limitations to advancing our understanding of Southern Ocean cephalopods is that they are notoriously difficult to catch through conventional, net-based sampling approaches (Rodhouse et al. 1996, Collins et al. 2004, Collins \& Rodhouse 2006, Xavier et al. 2007a). Therefore, much of our knowledge of cephalopods from the Southern Ocean has been acquired through studies of their predators (Cherel et al. 2004, Xavier \& Cherel 2009, Xavier et al. 2013b). For example, of the 40 or so cephalopod species recorded from seabird diet studies in the Southern Ocean, only 3 are commonly caught in net-haul samples (Clarke 1977, Rodhouse 1990, Cherel \& Klages 1998, Xavier et al. 2003b).

Defining diet is a crucial first step in order to better understand trophic interactions and hence build robust, meaningful marine food web models (Hill et al. 2012, Murphy et al. 2012), and identifying cephalopods from stomach contents is a standard technique. Increased knowledge of the morphology of cephalopod beaks (chitinous hard structures that resist digestion) has enabled identification to species level of most of the accumulated cephalopod beaks recovered from the stomachs of predators such as whales, seabirds and seals which prey on cephalopods (Clarke 1986, Imber 1992, Lu \& Ickeringill 2002, Xavier \& Cherel 2009, Xavier et al. 2011). This information can not only help in characterizing the diet of these predators, but also can provide useful insights into cephalopod species composition, distribution, abundance and ecology of the oceans within the range of the predators studied (Cherel et al. 2004,
Xavier et al. 2006, 2013b, Xavier \& Croxall 2007). This can be particularly important for understanding the ecology and status of cephalopod species that have not been subject to a commercial fishery, as is the case for Southern Ocean cephalopods (Collins \& Rodhouse 2006, Xavier et al. 2007b).

Albatrosses, including wandering albatrosses Diomedea spp., are cephalopod predators, which specialize in feeding on a wide range of oceanic squid and octopod species in subtropical waters in the north to Antarctic waters in the south (Imber 1992, Ridoux 1994, Cherel \& Klages 1998, Xavier et al. 2003). During the chick-rearing period, which can last up to $9 \mathrm{mo}$, wandering albatross adults may provide as many as 60 different cephalopod taxa to their chicks (Rodhouse et al. 1987, Imber 1992, Cherel \& Klages 1998, Xavier et al. 2003). Before fledging, albatross chicks voluntarily regurgitate a bolus (also known as a cast or pellet) of all indigestible items, including cephalopod beaks, retained during the chickrearing period (Xavier et al. 2005). These boluses represent a valuable non-invasive source of information regarding predator-prey interactions between albatrosses and their cephalopod prey (Xavier \& Cherel 2009, Xavier et al. 2011).

The Pacific sector of the Southern Ocean is considered one of the most poorly sampled areas for cephalopods (Griffiths 2010), though there is high demand for information on cephalopods from this region for building integrated food web models of the Southern Ocean (Murphy et al. 2012, Gutt et al. 2013, Xavier et al. 2013a, in press). The wandering albatross taxa breeding at Antipodes and Auckland Islands are closely related, with recent genetic work suggesting they should be regarded as a single species, Diomedea antipodensis (Burg \& Croxall 2004) but this issue remains a contentious decision and one that is likely to be revisited when new data are published. This is because the populations of $D$. antipodensis breeding at Antipodes and at Adams Island (as part of the Auckland Islands) are sometimes considered as sub-species: Antipodean albatross D. antipodensis antipodensis and Gibson's albatross D. antipodensis gibsoni, respectively (Miskelly et al. 2008, Robertson et al. 2013), as they exhibit different foraging areas (see next paragraph), are distinguishable genetically (Burg 2007), have different breeding cycles (Walker \& Elliott 2005) and can be sexed and differentiated by plumage alone (K. Walker \& $\mathrm{G}$. Elliott unpubl. data), Therefore, in this paper we consider that Gibson's wandering albatrosses D. antipodensis gibsoni and Antipodean wandering albatrosses $D$. antipodensis antipodensis as sub-species. 
The diet of both sub-species comprises fish and cephalopods, with the cephalopod component being analysed previously in detail in 2 studies (Imber \& Russ 1975, Imber 1992). No further investigations of their diets have been published in the last $20 \mathrm{yr}$. While there is a small overlap in distribution, Antipodean wandering albatrosses mostly forage in the Pacific Ocean east of New Zealand across to Chile and down to Antarctic waters, whereas Gibson's wandering albatrosses forage largely in and north of the subtropical convergence in the Tasman Sea and Great Australian Bight west of New Zealand (Walker \& Elliott 2006). Our main goal was to collect information on the cephalopod fauna inhabiting the Pacific sector of the Southern Ocean (and surrounding waters) using Antipodean and Gibson's wandering albatrosses as biological samplers, with a secondary goal of comparing the cephalopod component of their diets with results from previous studies across the Southern Ocean. Finally, we integrate our results to provide a broad overview of cephalopod biogeography in one of the most remote areas of the Southern Ocean.

\section{MATERIALS AND METHODS}

The boluses regurgitated voluntarily by Antipodean and Gibson's wandering albatross (Diomedea antipodensis antipodensis and D. antipodensis gibsoni, respectively) chicks were collected randomly from their nests at Antipodes Island $\left(49^{\circ} \mathrm{S}, 178^{\circ} \mathrm{E}\right)$ and Adams Island, Auckland Islands $\left(51^{\circ} \mathrm{S}, 166^{\circ} \mathrm{E}\right)$, respectively, between December 2001 and January 2002 (i.e. reflecting food delivered to albatross chicks between April and December in the 2001 breeding season).

The boluses were kept in plastic bags and frozen at $-20^{\circ} \mathrm{C}$ until analysed following Xavier et al. (2003) and Xavier \& Cherel (2009). Cephalopod beaks were cleaned and separated into upper and lower beaks. The upper beaks were counted and stored in $70 \%$ ethanol for later analyses, should there be substantial differences between the number of upper and lower beaks (Xavier et al. 2011). The lower beaks were identified and counted, measured (i.e. lower rostral length [LRL] for squid and lower hood length [LHL] for octopus species) using Vernier calipers (with a precision of $0.1 \mathrm{~mm}$ ). The identification of the lower beaks followed Xavier \& Cherel (2009), and the systematic order by Clarke (1986), and was checked against reference collections held at the British Antarctic Survey (UK), Centre d'Etudes Biologiques de Chizé (France) and at the National Institute of Water and Atmospheric Research (New Zealand). Beaks were classified as old or fresh according to Xavier \& Cherel (2009). For each taxa/family, frequency of occurrence, number and reconstructed mass was calculated, following Xavier et al. (2002). Allometric equations were used to relate the LRL for squid or the LHL for octopus species to the original wet body mass $(\mathrm{M}$, in $\mathrm{g}$ ) and the mantle length (ML, in $\mathrm{mm}$ ) following $\mathrm{Lu}$ \& Ickeringill (2002), Santos et al. (2002) and Xavier \& Cherel (2009). If allometric equations were not available for a given species, equations derived for the same family or of similar morphology/ecology were applied. The differences in the sizes of cephalopod species caught by both albatross species were compared using non-parametric Mann-Whitney tests, using the LRL following Cherel et al. (2004), of a minimum of 10 lower beaks of a cephalopod species in one of the albatross species. Values are given as mean \pm SD unless otherwise stated.

\section{RESULTS}

\section{Prey species}

The boluses from both the New Zealand wandering albatross sub-species contained mainly cephalopod beaks, but also seabird feathers and pieces of plastic. A total of 9111 beaks were analysed, of which 4855 were upper beaks and 4256 were lower beaks. All beaks were old (i.e. with no transparent parts nor flesh attached; Xavier \& Cherel 2009). The boluses from Antipodean wandering albatrosses Diomedea antipodensis antipodensis contained 2505 upper beaks and 2374 lower beaks ( $\mathrm{n}=25$ samples), and those from Gibson's wandering albatrosses $D$. antipodensis gibsoni contained 2350 upper beaks and 1882 lower beaks ( $\mathrm{n}=23$ samples), with $2.7 \%$ and $11.1 \%$ more upper beaks than lower beaks, respectively. As these percentage values are lower than $30 \%$ of difference between beak types, only lower beaks were identified, as suggested by Xavier et al. (2011). A total of 40 and 44 taxa of cephalopods were identified in Antipodean and Gibson's wandering albatross boluses, respectively (Table 1).

For Antipodean wandering albatrosses, the most frequently taken species was Histioteuthis atlantica (which occurred in $100 \%$ of the samples), followed by Taonius sp. B (Voss) (96\%), H. eltaninae (92\%), Galiteuthis glacialis (88\%) and Moroteuthis knipovitchi $(84 \%)$. Together, these species represented 


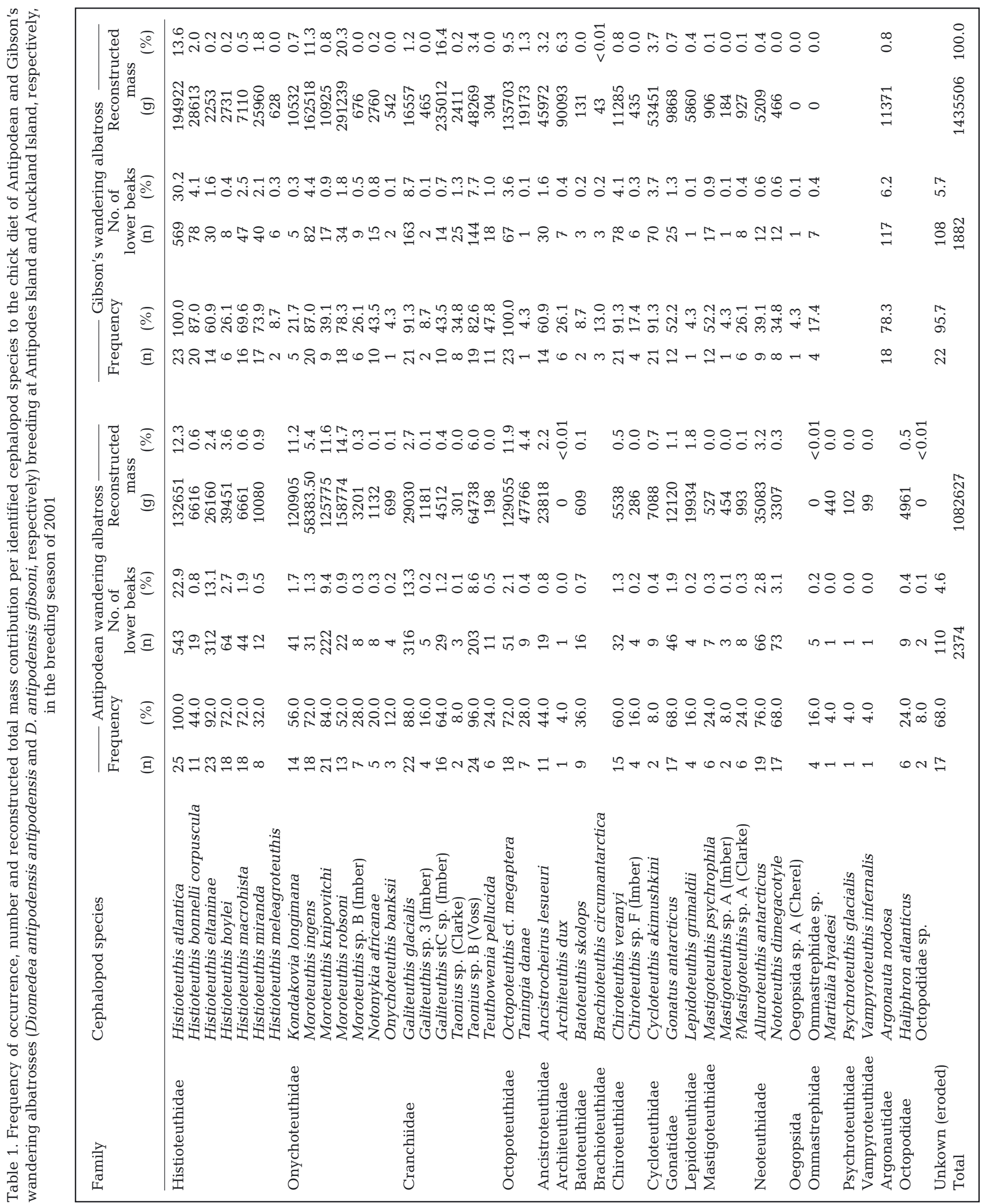


$67 \%$ of the total number of lower beaks (Table 1): $H$. atlantica was the most important species numerically $(23 \%$ by number), followed by G. glacialis $(13 \%)$. By reconstructed mass, $M$. robsoni $(15 \%), H$. atlantica (12\%), Octopoteuthis cf. megaptera (12\%), M. knipovitchi $(12 \%)$ and Kondakovia longimana $(11 \%)$ were the most important species. Along with Taonius sp. B (Voss) $(6 \%)$ and M. ingens (5\%), these 7 species (each represented by more than $5 \%$ by reconstructed mass) together contributed $73 \%$ by reconstructed mass of the cephalopod diet. $O$. cf. megaptera, K. longimana, M. ingens and M. robsoni were relatively less numerous (all 4 species combined, $6 \%$ by number) in the diet of Antipodean wandering albatrosses, but made a relatively large contribution to the reconstructed mass (combined, $43 \%$ ), whereas G. glacialis and $H$. eltaninae were numerous (13\% and $13 \%$ by number, respectively), but owing to the relatively small size of these species, accounted for a relatively small contribution to the reconstructed mass $(3 \%$ and $2 \%$, respectively; Table 1).

For Gibson's wandering albatrosses, H. atlantica was also the most frequent species (occurring in $100 \%$ of the samples) along with $O$. cf. megaptera $(100 \%)$, followed by G. glacialis, Chiroteuthis veranyi and Cycloteuthis akimushkini (Table 1). There were only 4 species represented by more than $5 \%$ by number, and these combined contributed only $53 \%$ of the total number of lower beaks; $H$. atlantica was by far the most important species numerically, with $30 \%$ by number (Table 1 ). By reconstructed mass, 6 species each represented more than $5 \%$ of the total: M. robsoni (20\%), Galiteuthis stC sp. (Imber) (16\%), $H$. atlantica $(14 \%), M$. ingens $(11 \%), O$. cf. megaptera $(9 \%)$ and Architeuthis dux $(6 \%)$. Combined, these 6 species contributed $77 \%$ by reconstructed mass to the cephalopod component of the albatross chick diet. Relatively large species, such as $M$. ingens, $O$. cf. megaptera, M. robsoni, A. dux and Galiteuthis stC sp. (Imber), were relatively less numerous (combined, 11\%), but made a relatively large contribution to the reconstructed mass (combined, $64 \%$; Table 1). On the other hand, G. glacialis, Taonius sp. B (Voss) and Argonauta nodosa were relatively numerous $(9 \%, 8 \%$ and $6 \%$ by number, respectively) but owing to these species relatively small size, represented a relatively modest contribution to the reconstructed mass $(3 \%, 1 \%$ and $0.8 \%$ by reconstructed mass, respectively; Table 1).

Comparing the cephalopod components of both New Zealand wandering albatross sub-species, the cephalopod species which were only consumed by
Antipodean wandering albatrosses were Haliphron atlanticus, Martialia hyadesi, Psychroteuthis glacialis and Vampyroteuthis infernalis; whereas Oegopsida sp. A (Cherel), Histioteuthis meleagroteuthis, Brachioteuthis circumantarctica, Architeuthis dux and Argonauta nodosa were only consumed by Gibson's wandering albatrosses (Table 1).

Numerically, both New Zealand wandering albatross sub-species fed mainly on cephalopods from the Family Histioteuthidae $(42 \%$ and $41 \%$ by number for Antipodean and Gibson's wandering albatrosses, respectively), with Onychoteuthidae (particularly in the diet of Antipodean wandering albatrosses; $43 \%$ by reconstructed mass), Cranchiidae and Octopoteuthidae becoming important by reconstructed mass. In Gibson's wandering albatrosses, the contribution by reconstructed mass is more evenly distributed between these 4 families (Table 1). The main differences between the cephalopod diet of the 2 albatross sub-species are the absence of Argonauta nodosa in Antipodean wandering albatrosses (this cephalopod species was relatively important numerically, at $6 \%$, in the diet of Gibson's wandering albatrosses; Table 1), the relatively high importance in terms of reconstructed mass of Architeuthis dux and Galiteuthis stC sp. (Imber; 16\%) in Gibson's wandering albatross diets, and the relatively high numerical importance of $H$. eltaninae $(13 \%), M$. knipovitchi $(9 \%)$ and $K$. longimana ( $2 \%$; Table 1$)$ in the Antipodean wandering albatross diet.

\section{Prey size}

Both Antipodean and Gibson's wandering albatross sub-species fed on adult cephalopods (all beaks had darkened wings), with the heaviest specimen being that of Architeuthis dux (13.5 mm LRL, estimated $45.5 \mathrm{~kg}, 747 \mathrm{~mm} \mathrm{ML}$ ) collected from a Gibson's wandering albatross. Antipodean wandering albatrosses fed on relatively smaller squids (ranging from 8.5 to 933.2 $\mathrm{mm} \mathrm{ML}$ ) than Gibson's wandering albatrosses (ranging from 10.9 to 1179.2 mm ML; Fig. 1); the only octopod in the Antipodean wandering albatross diet was Haliphron atlanticus, which can reach large ML sizes (i.e. up to $22908 \mathrm{~mm} \mathrm{ML}$ ), and in Gibson's wandering albatross, it was Argonauta nodosa, which reaches up to $121 \mathrm{~mm}$ ML (Table S1 in the Supplement at www.int-res.com/articles/suppl/m513p131_supp. pdf).

Overall, both wandering albatross sub-species fed on different sizes of 8 cephalopod species and on similar sizes of 11 cephalopod species (Table S1; 


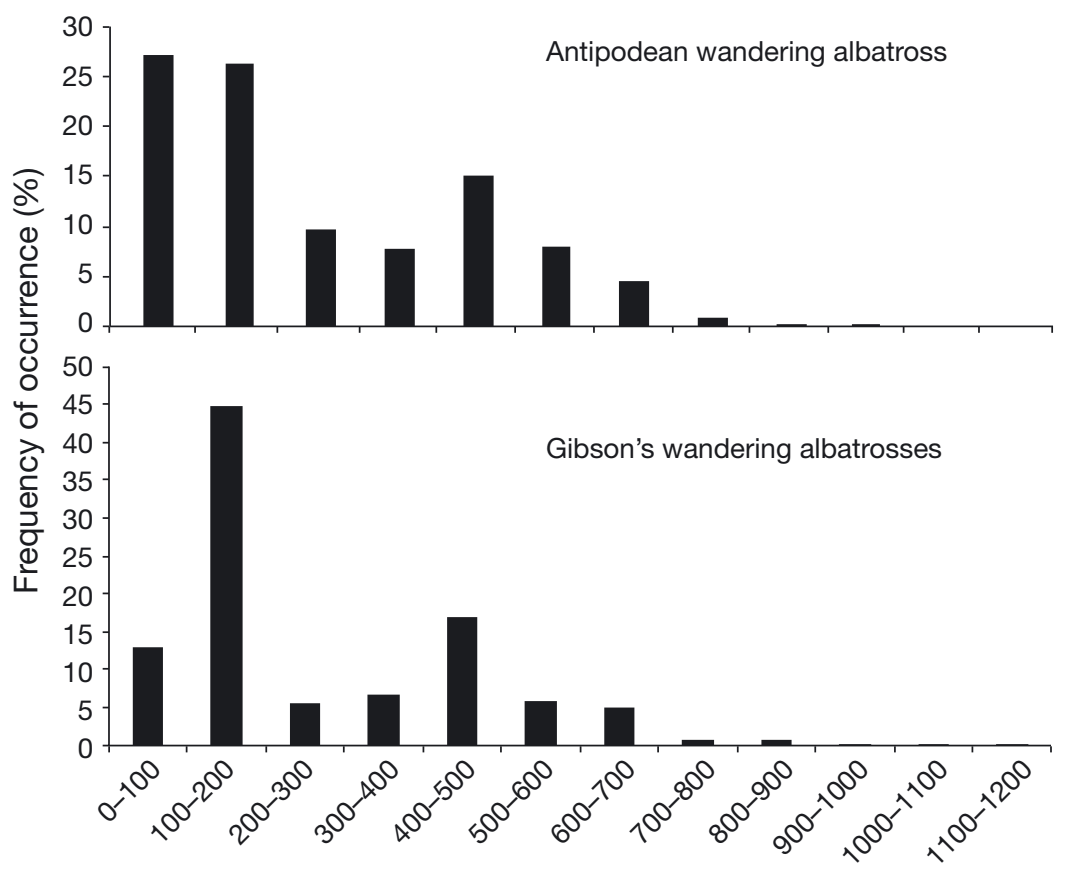

Mantle length $(\mathrm{mm})$

Fig. 1. Frequency of occurrence of all squid species by mantle length in the diet of Antipodean wandering albatrosses Diomedea antipodensis antipodensis (upper panel) and Gibson's wandering albatrosses D. antipodensis gibsoni (lower panel) from Antipodes and Auckland islands, respectively, in the breeding season of 2001

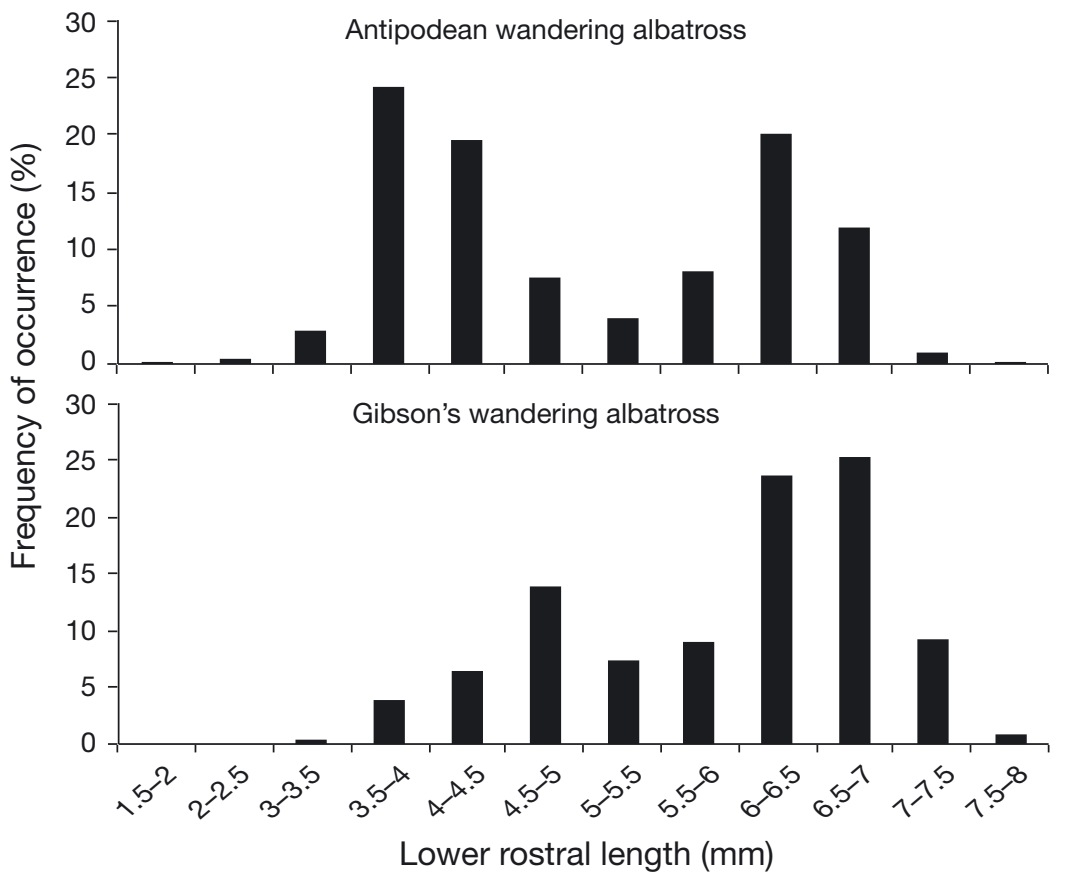

Fig. 2. Frequency of occurrence of Histioteuthis atlantica by lower rostral length in the diet of Antipodean wandering albatrosses Diomedea antipodensis antipodensis (upper panel) and Gibson's wandering albatrosses $D$. antipodensis gibsoni (lower panel) from Antipodes and Auckland islands, respectively, in the breeding season of 2001 when comparing the LRL between the same cephalopod species from both albatross sub-species). For example, $H$. atlantica (the most important cephalopod species, by frequency of occurrence and numerically) was consumed by both Antipodean and Gibson's wandering albatrosses and showed a bimodal frequency distribution of sizes taken: Antipodean wandering albatrosses fed on smaller sizes (modes: 3.5-4.0 and 6.0-6.5 mm LRL) compared to Gibson's wandering albatrosses (modes: 4.5-5.0 and 6.5-7.0 mm LRL; Fig. 2). H. atlantica was the only cephalopod species to exhibit such a bimodal frequency distribution. G. glacialis, on the other hand, was consumed by both albatross sub-species over a similar size range (mode: 5.0-5.5 mm LRL; Fig. 3).

\section{DISCUSSION}

\section{Cephalopod diet of wandering albatrosses breeding in New Zealand Islands}

The overall diet of Antipodean and Gibson's wandering albatrosses (Diomedea antipodensis antipodensis and D. antipodensis gibsoni, respectively) breeding in the New Zealand region is unknown. Based on diet data from other wandering albatross populations, the cephalopod component is likely to represent more than $50 \%$ of the diets, with fish being the other major component (Cherel \& Klages 1998, Xavier et al. 2004). One of the primary aims of the present study was to provide a detailed and comparative assessment of the cephalopod component in the diet of Antipodean and Gibson's wandering albatrosses.

The relatively large diversity of cephalopods eaten and the differences in the proportion of each cephalopod species in the diet of the 2 New Zealand wandering albatross sub-species studied confirmed the findings from a limited number of earlier studies based on a much smaller number of samples collected in the 1970s and 1980s which were pooled and analysed together (Imber \& Russ 1975, Imber 1992). When comparing our results from both wandering albatross sub-species (samples 


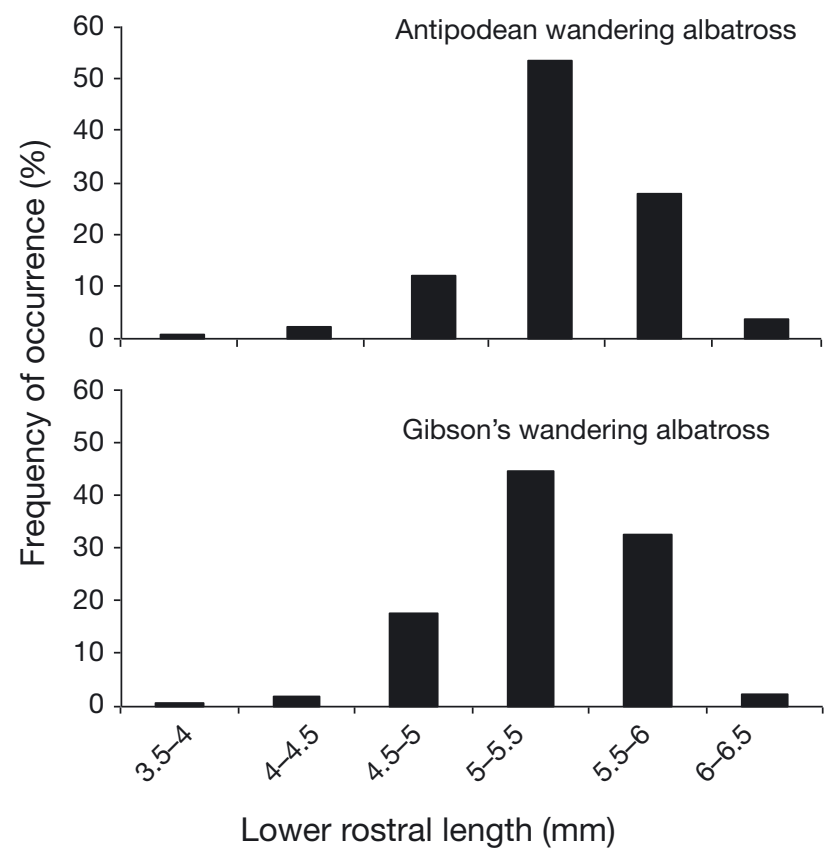

Fig. 3. Frequency of occurrence of Galiteuthis glacialis by lower rostral length in the diet of Antipodean wandering albatrosses Diomedea antipodensis antipodensis (upper panel) and Gibson's wandering albatrosses D. antipodensis gibsoni (lower panel) from Antipodes and Auckland islands, respectively, in the breeding season of 2001

collected in 2001) with the samples collected in 1973, 1975 and 1985 (Imber \& Russ 1975, Imber 1992), the most important cephalopod families remain consistent across all years (Histioteuthidae by number and Onychoteuthidae by reconstructed mass), with Histioteuthis atlantica being the most important by number (Table S2 in the Supplement at www.int-res.com/ articles/suppl/m513p131_supp.pdf), suggesting that New Zealand wandering albatrosses' diet has not markedly changed between decades. However, in terms of reconstructed mass, Kondakovia longimana, which was the most important cephalopod species in Antipodean wandering albatrosses' diet in the 1970s and $1980 \mathrm{~s}$, was replaced in importance by Moroteuthis robsoni in 2001 (Table S2). For Gibson's wandering albatrosses, M. robsoni in the 1970s and 1980s was superseded by $H$. atlantica in 2001 as the most important cephalopod species in the diet by reconstructed mass (Table S2). Two further temporal differences in the diets of New Zealand wandering albatross sub-species are worth mentioning: firstly, the increase in importance of the Family Octopoteuthidae, with the poorly known Octopoteuthis cf. megaptera, increasing in the diet of Antipodean wandering albatrosses from $2 \%$ in 1970s/1980s to $16 \%$ in 2001(by reconstructed mass), and Argonauta nodosa increasing in importance in the diet of Gibson's wandering albatrosses from $1 \%$ in $1970 \mathrm{~s} / 1980 \mathrm{~s}$ to $6 \%$ by number in 2001, thereby becoming the 4 th most numerous species taken in 2001.

\section{Cephalopod assemblages targeted by wandering albatrosses across the Southern Ocean}

Assessing the cephalopod diet of wandering albatrosses according to the latitudinal gradient of the location of their breeding colonies (from south to north: South Georgia in the low Antarctic zone, Crozet and Marion Islands in the Antarctic Frontal Zone, and Auckland, Antipodes and Gough Islands in subantarctic waters), we noticed the following:

The cephalopod families Onychoteuthidae, Cranchiidae and Histioteuthidae are important numerically in the diet of wandering albatrosses Diomedea exulans breeding in Antarctic waters at South Georgia (with additionally Ommastrephidae in one year in the 1980s: our Table S3 in the Supplement; Rodhouse et al. 1987), in the Atlantic sector of the Southern Ocean (Table S3). By reconstructed mass, the Family Onychoteuthidae dominated at South Georgia (Clarke et al. 1981, Rodhouse et al. 1987, Xavier et al. 2003). At Marion Island and Crozet Islands, in the Indian Ocean sector of the Southern Ocean, the Family Onychoteuthidae dominated by number and by reconstructed mass in the diet of wandering albatrosses, mostly due to $K$. longimana. In contrast, at Gough Island, located further to the north (in subantarctic waters), the Family Histioteuthidae dominated both by number and by reconstructed mass in the diet of Tristan albatross Diomedea dabbenena (our Table S3; Imber 1992), as it did in the present study at the subantarctic Antipodes and Auckland Islands (i.e. Family Histioteuthidae being the most important by number and Family Onychoteuthidae by mass; Table 1). Such results reflect the latitude of the breeding colonies of wandering albatrosses, with a higher number of subtropical cephalopod species in the northern breeding colonies (our Tables S2 \& S3; Ridoux 1994, Xavier et al. 2003b). Indeed, cephalopod diversity seems to decline with increasing latitude, e.g. as seen when evaluating the diet of Patagonian toothfish Dissostichus eleginoides (as local cephalopod predators providing an insight into cephalopod fauna in a region): 29 taxa are found in Crozet waters (located within the Polar Frontal Zone), whereas only 16 taxa are found in the colder South Georgia waters (located in Antarctic waters), with all of these cephalopod taxa also occurring at Crozet (Xavier et al. 2002, Cherel et al. 2004). 
The cephalopods taken by wandering albatrosses in our study were of similar size to those taken previously in other studies (with comparable data for the same identified species) on wandering albatrosses from the Atlantic and Indian Ocean sectors of the Southern Ocean (Ridoux 1994, Xavier et al. 2003). One of the main exceptions was Gonatus antarcticus, of which comparatively large individuals occurred in the diet of Gibson's wandering albatrosses (mean LRL: $7.3 \pm 0.6 \mathrm{~mm}$; Table $\mathrm{S} 1$ ) relative to Antipodean wandering albatross diets (mean LRL: $6.4 \pm 0.8 \mathrm{~mm}$; Table S1) or in the diet of wandering albatrosses at South Georgia (mean LRL: $6.3 \pm 0.0 \mathrm{SE} \mathrm{mm;} \mathrm{Xavier} \mathrm{et}$ al. 2003b). Conversely, K. longimana occurs in a relatively wide range of sizes in the diet of wandering albatrosses at South Georgia (K. longimana, mean LRL: $13.7 \pm 0.1 \mathrm{SE} \mathrm{mm;} \mathrm{range:} \mathrm{5.3-22.3} \mathrm{mm} \mathrm{LRL;}$ Xavier et al. 2003b), whereas those taken by Antipodean wandering albatrosses, though on average larger, were more restricted in range of sizes (mean LRL: $14.2 \pm 1.7 \mathrm{~mm}$; range: $10.7-18.4 \mathrm{~mm}$ LRL; Table S1), a feature first noted by Imber (1992). These species-specific differences most likely reflect differences in the sea temperature-determined availability and/or abundance of cephalopods between the differing latitude breeding grounds of wandering albatrosses, as suggested by Imber (1992), Xavier et al. (2003b) and Cherel et al. (2004).

\section{Cephalopod fauna from the Pacific sector of the Southern Ocean}

Antipodean and Gibson's wandering albatrosses proved to be valuable biological samplers of cephalopods in the Pacific sector of the Southern Ocean, in keeping with previous studies utilizing apex predators (Clarke et al. 1981, Rodhouse et al. 1987, Cherel \& Weimerskirch 1999, Xavier et al. 2003). We were able to provide new information on the trophic role, as prey, of some cephalopod taxa for which almost no biological information is available. These include Galiteuthis stC sp. (Imber), a significant species by reconstructed mass (16.4\%; Table 1) in Gibson's wandering albatross diets (Table 1), but which have been recorded in the diet of only a very small number of other predators, including Patagonian toothfish D. eleginoides in Crozet waters (Cherel et al. 2004). Similarly, the present study found that the cephalopod species Taonius sp. (Clarke), Moroteuthis sp. B (Imber), Galiteuthis sp. 3 (Imber), Chiroteuthis sp. F, ?Mastigoteuthis sp. A (Clarke), Mastigoteuthis sp. A (Imber) and Oegopsida sp. A (Cherel) were taken by
New Zealand wandering albatrosses, but they have only occasionally been recorded in the diet of other predators, including albatrosses, Patagonian toothfish, penguins and tuna (Young et al. 1997, Tremblay \& Cherel 2003, Xavier et al. 2003, Cherel et al. 2004), and their biology and ecology remain virtually unknown. Remarkably, only a single specimen of Taonius has ever been captured once in the Southern Ocean using net sampling (Rodhouse 1990), although beak analyses show that Taonius spp. (including Taonius sp. B (Voss)) are eaten by not just the New Zealand wandering albatrosses (Imber 1992, present study), but also by a wide range of other predators across the Southern Ocean, including 5 other species of albatrosses and petrels, sharks, Patagonian toothfish and whales (Xavier \& Cherel 2009, present study). Finally, the cosmopolitan species A. nodosa, which is distributed worldwide in temperate waters (including south of Australia), occurred in relatively high numbers in the diet of Gibson's wandering albatrosses (which forage extensively in temperate waters; Walker \& Elliott 2006); in contrast, previous top-predator studies noted this species in relatively low numbers (Cockcroft et al. 1993, Hume et al. 2004, Baldassin et al. 2010), and it has never been recorded in conventional net-sampling studies in the colder waters of the Southern Ocean (Table 2). Without studies such as the present one investigating the composition of the diet of marine predators, we would know much less about the distribution and habitat requirements of cephalopods, despite their crucial role as keystone species within the marine environment.

\section{Biogeography of cephalopods of the Southern Ocean}

Antipodean and Gibson's wandering albatross populations forage over relatively large areas of the central south and west Pacific sector of the Southern Ocean respectively during their breeding season (Walker \& Elliott 2006), so we can draw some firm conclusions about which cephalopod species occur in these waters, albeit at a relatively large scale. Furthermore, as diet and foraging data are available for other wandering albatrosses, and other apex predators, from the Atlantic and Indian sectors of the Southern Ocean (Table 2), we can additionally assess with some certainty, in comparison with cephalopod data from nets (Table 2), which cephalopod species have a circumpolar distribution. A total of 28 cephalopod taxa, from 17 families, have a cir- 


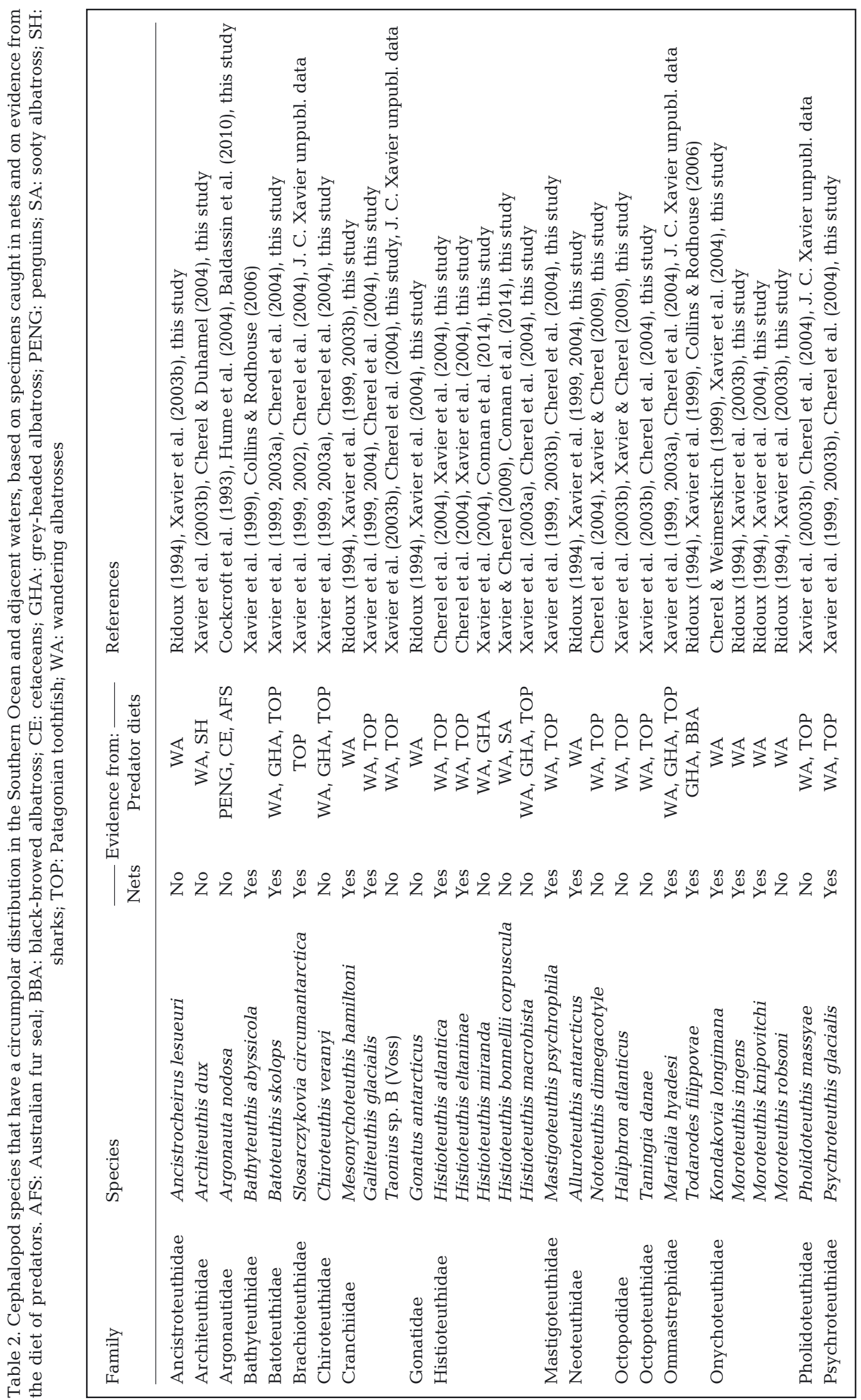


cumpolar distribution (Table 2). The majority of the most important cephalopod species in the diet of Antipodean and Gibson's wandering albatrosses are known to exhibit a circumpolar distribution: H. atlantica, H. eltaninae, M. knipovitchi, Galiteuthis glacialis, Taonius sp. B (Voss), K. longimana, M. robsoni, M. ingens, Argonauta nodosa and Architeuthis dux (Table 2). There is no evidence that the other 2 species that are relatively important taxa in the diets of the New Zealand wandering albatrosses are circumpolar: Galiteuthis stC sp. (Imber) is only known to occur in the Indian and Pacific sectors of the Southern Ocean, based on the diets of local predators (Imber 1992, Cherel et al. 2004). Various Octopoteuthis spp. (including $O$. cf. megaptera) do occur throughout the Southern Ocean in predators diets (Ridoux 1994, Xavier et al. 2003), but the beaks of species in this family need to be further reviewed in order to resolve taxonomic relationships. Cephalopod species with circumpolar distributions, and life cycles that may allow relatively high numbers of adult cephalopods to be available to albatrosses in surface waters (Xavier \& Croxall 2007, Xavier et al. 2013b), appear to represent a reliable prey source, and constitute an important component in the diet of wandering albatrosses across the entire Southern Ocean. In the future, if the distributions of lower trophic level organisms, such as squid, shift south due to environmental change (IPCC 2013, Rodhouse 2013, Constable et al. 2014), more warm water cephalopod species and fewer cold water species (depending on albatross ability to adapt their foraging to prey abundance/availability and distribution) may be found in the diets of wandering albatrosses. Our study on the diets of wandering albatrosses (bring a comparison between data from the 1970s, 1980s and 2000s) provides a baseline contributing study to assess Southern Ocean ecosystem change and dynamics in future decades.

Predicting the distribution of cephalopod species of the Southern Ocean according to water masses, using wandering albatrosses as biological samplers, has already been attempted with some success (Xavier et al. 2006). However, further work would be required to clearly delineate cephalopod species according to water mass, as it is not possible to be totally confident where an albatross consumed each prey item in their long foraging trips. Indeed, isotopic work to delineate cephalopod distributions in more detail is underway to properly address this issue.

Future work should focus on improving the allometric equations (Xavier et al. 2007a, 2014) to better reconstruct mass estimates but also explore the impact of scavenging in the estimates of albatross food consumption. It is unlikely that an individual wandering albatross would be able to consume the largest individuals of certain species (e.g. K. longimana). Also, it is also possible that certain albatross individuals may target parts of a squid (e.g. buccal masses, eyes), which would over-inflate the reconstructing mass estimates at an individual level. However, from a population perspective, wandering albatrosses may aggregate to consume these larger individuals together (i.e. obtaining pieces of these larger squid through tearing and pulling may be easier), reducing such over-inflating estimates of squid consumption. Therefore, assessing albatross behaviour at sea and comparing the percentage of diet estimated by reconstructed mass from beaks with the percentage of the diet obtained from complementary biochemical analyses, such as stable isotope or fatty acid analyses, should also be included in future research.

Finally, future work on the description of the complete diet of Antipodean and Gibson's wandering albatrosses, assessment of the inter-annual variations in their diets (including the cephalopod component) and research cruises targeting the larger cephalopod species commonly found in this study (Xavier et al. 2014) is highly desirable, as the biology of these is still virtually unknown.

Acknowledgements. We thank Josh Kemp and Chris Rickard for collecting the samples from Antipodes Island and Soniya McArtney, Sadie Mills and Kareen Schnabel for their contributions in preparing and facilitating the analyses of the beak samples at the National Institute of Water and Atmospheric Research (NIWA). The collection work was supported by the Conservation Services Programme of the New Zealand Department of Conservation and analyses by the Ministry of Science and Higher Education, Portugal (Fundação para a Ciência e a Tecnologia) and the British Antarctic Survey, under the research programmes CEPH (within the British Antarctic Survey Ecosystems Program), Scientific Committee for Antarctic Research program (SCAR) AnT-ERA, Portuguese Polar Program PROPOLAR and Integrating Climate and Ecosystem Dynamics of the Southern Ocean (ICED).

\section{LITERATURE CITED}

André J, Haddon M, Pecl GT (2010) Modelling climatechange-induced nonlinear thresholds in cephalopod population dynamics. Glob Change Biol 16:2866-2875

Baldassin P, Santos RA, Cunha JMM, Werneck MR, Gallo H (2010) Cephalopods in the diet of Magellanic penguins Spheniscus magellanicus found on the coast of Brazil. Mar Ornithol 38:55-57

Boyle P, Rodhouse PG (2005) Cephalopods ecology and fisheries. Blackwell Science, Oxford

Burg TM (2007) Genetic analysis of wandering albatrosses 
killed in longline fisheries off the east coast of New Zealand. Aquat Conserv Mar Freshw Ecosyst 17:S93-S101

- Burg TM, Croxall JP (2004) Global population structure and taxonomy of the wandering albatross species complex. Mol Ecol 13:2345-2355

Cherel Y, Duhamel G (2004) Antarctic jaws: cephalopod prey of sharks in Kerguelen waters. Deep-Sea Res I 51: $17-31$

Cherel Y, Klages N (1998) A review of the food of albatrosses. In: Robertson G, Gales R (eds) Albatross biology and conservation. Surrey Beatty \& Sons, Chipping Norton, p 113-116

> Cherel Y, Weimerskirch H (1999) Spawning cycle of onychoteuthid squids in the southern Indian Ocean: new information from seabird predators. Mar Ecol Prog Ser 188: 93-104

> Cherel Y, Duhamel G, Gasco N (2004) Cephalopod fauna of subantarctic islands: new information from predators. Mar Ecol Prog Ser 266:143-156

Clarke MR (1977) Beaks, nets and numbers. Symp Zool Soc Lond 38:89-126

Clarke MR (1986) A handbook for the identification of cephalopod beaks. Clarendon Press, Oxford

Clarke MR, Croxall JP, Prince PA (1981) Cephalopod remains in regurgitations of the wandering albatross at South Georgia. Br Antarct Surv Bull 54:9-22

Cockcroft VG, Hashick SL, Klages NTW (1993) The diet of Risso's dolphin, Grampus griseus (Cuvier, 1812), from the east coast of South Africa. Z Saeugetierkd 58:286-293

Collins MA, Rodhouse PGK (2006) Southern Ocean cephalopods. Adv Mar Biol 50:191-265

Collins MA, Allcock AL, Belchier M (2004) Cephalopods of the South Georgia slope. J Mar Biol Assoc UK 84: 415-419

Connan M, McQuaid CD, Bonnevie BT, Smale MJ, Cherel Y (2014) Combined stomach content, lipid and stable isotope analyses reveal spatial and trophic partitioning among three sympatric albatrosses from the Southern Ocean. Mar Ecol Prog Ser 497:259-272

> Constable AJ, Melbourne-Thomas J, Corney SP, Arrigo K and others (2014) Climate change and Southern Ocean ecosystems I: how changes in physical habitats directly affect marine biota. Glob Change Biol 20:3004-3025

Griffiths HJ (2010) Antarctic marine biodiversity: What do we know about the distribution of life in the Southern Ocean? PLoS ONE 5:e11683

Gutt J, Adams B, Bracegirdle T, di Prisco G and others (2013) Antarctic Thresholds - Ecosystem Resilience and Adaptation (AnT-ERA), a new SCAR-biology program. Polarforschung 82:147-150

- Hill SL, Keeble K, Atkinson A, Murphy EJ (2012) A food web model to explore uncertainties in the South Georgia shelf pelagic ecosystem. Deep-Sea Res II 59-60:237-252

Hume F, Hindell MA, Pemberton D, Gales R (2004) Spatial and temporal variation in the diet of a high trophic level predator, the Australian fur seal (Arctocephalus pusillus doriferus). Mar Biol 144:407-415

> Hunsicker ME, Essington TE, Watson R, Sumaila UR (2010) The contribution of cephalopods to global marine fisheries: Can we have our squid and eat them too? Fish Fish 11:421-438

Imber MJ (1992) Cephalopods eaten by wandering albatrosses Diomedea exulans L. breeding at six circumpolar localities. J R Soc NZ 22:243-263

Imber MJ, Russ R (1975) Some foods of the wandering alba- tross (Diomedea exulans). Notornis 22:27-36

IPCC (Intergovernmental Panel on Climate Change) (2013) Summary for policymakers. In: Stocker TF, Qin D, Plattner GK, Tignor M and others (eds) Climate change 2013: the physical science basis. Contribution of Working Group I to the Fifth Assessment Report of the Intergovernmental Panel on Climate Change. Cambridge University Press, Cambridge, p 3-29

Lu CC, Ickeringill R (2002) Cephalopod beak identification and biomass estimation techniques: tools for dietary studies of southern Australian finfishes. Mus Victoria Sci Rep 6:1-65

Miskelly CM, McNally N, Seymour R, Gregory-Hunt D, Lanauze J (2008) Antipodean wandering albatrosses (Diomedea antipodensis) colonising the Chatham Islands. Notornis 55:89-95

> Murphy EJ, Watkins JL, Trathan PN, Reid K and others (2007) Spatial and temporal operation of the Scotia Sea ecosystem: a review of large-scale links in a krill centred food web. Philos Trans R Soc Lond B Biol Sci 362: 113-148

- Murphy EJ, Cavanagh RD, Hofmann EE, Hill SL and others (2012) Developing integrated models of Southern Ocean food webs: including ecological complexity, accounting for uncertainty and the importance of scale. Prog Oceanogr 102:74-92

Pecl GT, Jackson GD (2008) The potential impacts of climate change on inshore squid: biology, ecology and fisheries. Rev Fish Biol Fish 18:373-385

Ridoux V (1994) The diets and dietary segregation of seabirds at the Subantarctic Crozet Islands. Mar Ornithol 22: $1-192$

Robertson HA, Dowding JE, Elliott GP, Hitchmough RA and others (2013) Conservation status of New Zealand birds, 2012. New Zealand Threat Classification Series 4. Department of Conservation, Wellington

Rodhouse PG (1990) Cephalopod fauna of the Scotia Sea at South Georgia: potential for commercial exploitation and possible consequences. In: Kerry KR, Hempel G (eds) Antarctic ecosystems: ecological change and conservation. Springer-Verlag, Berlin, p 289-298

> Rodhouse PG (2013) Role of squid in the Southern Ocean pelagic ecosystem and the possible consequences of climate change. Deep-Sea Res II 95:129-138

> Rodhouse PG, Clarke MR, Murray AWA (1987) Cephalopod prey of the wandering albatross Diomedea exulans. Mar Biol 96:1-10

- Rodhouse PG, Prince PA, Trathan PN, Hatfield EMC and others (1996) Cephalopods and mesoscale oceanography at the Antarctic Polar Front: satellite tracked predators locate pelagic trophic interactions. Mar Ecol Prog Ser 136:37-50

Rodhouse PG, Xavier JC, Griffiths H (2014) Southern Ocean squid. In: De Broyer C, Koubbi P, Griffiths H, Danis B and others (eds) The CAML/SCAR-MarBIN biogeographic atlas of the Southern Ocean. Scientific Committee on Antarctic Research, Cambridge, p 284-298

Roeleveld MAC (1998) The status and importance of cephalopod systematics in Southern Africa. S Afr J Mar Sci 20:1-16

> Santos MB, Pierce GJ, Hartmann MG, Smeek C and others (2002) Additional notes on stomach contents of sperm whales Physeter macrocephalus stranded in the northeast Atlantic. J Mar Biol Assoc UK 82:501-507

Tremblay Y, Cherel Y (2003) Geographic variation in the for- 
aging behaviour, diet and chick growth of rockhopper penguins. Mar Ecol Prog Ser 251:279-297

Walker K, Elliott G (2005) Population changes and biology of the Antipodean albatross (Diomedea antipodensis). Notornis 52:206-214

Walker K, Elliott G (2006) At-sea distribution of Gibson's and Antipodean wandering albatrosses, and relationships with longline fisheries. Notornis 53:265-290

Xavier JC, Cherel Y (2009) Cephalopod beak guide for the Southern Ocean. British Antarctic Survey, Cambridge

Xavier JC, Croxall JP (2007) Predator-prey interactions: Why do larger albatrosses feed on bigger squid? J Zool 271:408-417

Xavier JC, Rodhouse PG, Trathan PN, Wood AG (1999) A Geographical Information System (GIS) atlas of cephalopod distribution in the Southern Ocean. Antarc Sci 11: 61-62

Xavier JC, Rodhouse PG, Purves MG, Daw TM, Arata J, Pilling GM (2002) Distribution of cephalopods recorded in the diet of Patagonian toothfish (Dissostichus eleginoides) around South Georgia. Polar Biol 25:323-330

> Xavier JC, Croxall JP, Trathan PN, Wood AG (2003a) Feeding strategies and diets of breeding grey-headed and wandering albatrosses at South Georgia. Mar Biol 143: 221-232

Xavier JC, Croxall JP, Trathan PN, Rodhouse PG (2003b) Inter-annual variation in the cephalopod component of the diet of wandering albatrosses Diomedea exulans breeding at Bird Island, South Georgia. Mar Biol 142: 611-622

Xavier JC, Trathan PN, Croxall JP, Wood AG, Podestá GP, Rodhouse PG (2004) Foraging ecology and interactions with fisheries of wandering albatrosses at South Georgia. Fish Oceanogr 13:324-344

Xavier JC, Croxall JP, Cresswell KA (2005) Boluses: an effective method to assess the proportions of cephalopods in the diet of albatrosses. Auk 122:1182-1190

Xavier JC, Geraint GA, Croxall JP (2006) Determining large

Editorial responsibility: Scott Shaffer,

San Jose, California, USA scale distribution of pelagic cephalopods, fish and crustaceans in the South Atlantic from wandering albatross (Diomedea exulans) foraging data. Ecography 29:260-272

Xavier JC, Clarke MR, Magalhães MC, Stowasser G, Blanco C, Cherel Y (2007a) Current status of using beaks to identify cephalopods: III international workshop and training course on cephalopod beaks, Faial Island, Azores, April 2007. Arquipélago Life Mar Sci 24:41-48

Xavier JC, Wood AG, Rodhouse PG, Croxall JP (2007b) Interannual variations in cephalopod consumption by albatrosses at South Georgia: implications for future commercial exploitation of cephalopods. Mar Freshw Res 58:1136-1143

Xavier JC, Phillips RA, Cherel Y (2011) Cephalopods in marine predator diet assessments: why identifying upper and lower beaks is important. ICES J Mar Sci 68: 1857-1864

Xavier JC, Barbosa A, Agusti S, Alonso-Sáez L and others (2013a) Polar marine biology science in Portugal and Spain: recent advances and future perspectives. J Sea Res 83:9-29

> Xavier JC, Cherel Y, Roberts J, Piatkowski U (2013b) How do cephalopods become available to seabirds: Can fish gut contents from tuna fishing vessels be a major food source of deep-dwelling cephalopods? ICES J Mar Sci 70:46-49

> Xavier JC, Allcock L, Cherel Y, Lipinski MR and others (2014) Future challenges in cephalopod research. J Mar Biol Assoc UK (in press), doi:10.1017/S0025315414000782

Xavier JC, Hill SL, Belchier M, Bracegirdle TJ, Murphy EJ, Lopes-Dias $\mathrm{J}$ (in press) From ice to penguins: the role of mathematics in Antarctic research. In: Pinto A (ed) Springer-Verlag, New York, NY

Young JW, Lamb TD, Duyet LR, Bradford RW, Whitelaw AW (1997) Feeding ecology and interannual variations in diet of southern bluefin tuna, Thunnus maccoyii, in relation to coastal and oceanic waters off eastern Tasmania, Australia. Environ Biol Fishes 50:275-291

Submitted: May 28, 2014; Accepted: July 18, 2014 Proofs received from author(s): September 29, 2014 